\title{
Effect of Barium in Porcelain on Bonding Strength of Titanium-Porcelain System
}

\author{
Kenji OKA, Takao HANAWA ${ }^{1}$, Masayuki KON ${ }^{1}$, Hae-Hyoung LEE $^{1}$, Fumiaki KAWANO, \\ Yoritoki TOMOTAKE, Naoyuki MATSUMOTO and Kenzo ASAOKA ${ }^{1}$ \\ Department of Removal Prosthodontics and ${ }^{1}$ Department of Dental Engineering, Tokushima University \\ School of Dentistry, 3 Kuramoto-cho, Tokushima 770, Japan
}

Received July 29, 1996/Accepted October 26, 1996

\begin{abstract}
The bonding strength to titanium, thermal expansion, and bending strength of glassy porcelain containing barium of 5,10 , and 15 mass\% were estimated and compared with those of barium-free porcelain, to estimate the effect of barium content on bonding strength to titanium. The three different glassy porcelains containing barium were made by melting at $950^{\circ} \mathrm{C}$. The bonding strength of a commercial porcelain to titanium increased with the addition of barium. Bending strength and thermal expansion were not affected by the barium content. Therefore, the addition of barium to porcelain is effective for strengthening the bonding of porcelain to titanium.
\end{abstract}

Key words : Porcelain for titanium, Bonding strength, Barium

\section{INTRODUCTION}

Various casting processes have been developed for titanium in dentistry, some of which are used commercially. From the success of these casting procedures, the bonding of porcelain to titanium has been attempted, and several porcelains for bonding to titanium are now available commercially. Bonding strength is important not only for porcelain bonding to titanium but also for other alloys. Bonding is primarily governed by a reaction layer existing between porcelain and titanium that is formed by the mutual diffusion of elements. In this regard, porcelain-fused-to-titanium systems have been studied. Togaya et al. ${ }^{1)}$ investigated the feasibility of using titanium in a metal-porcelain system, and demonstrated the advantages of the system with regard to the thermal expansion and mechanical properties of titanium at high temperatures. Adachi $e t$ al. ${ }^{2)}$ reported the relationship between the oxidation of titanium and $\mathrm{Ti}-6 \mathrm{Al}-4 \mathrm{~V}$ and bonding strength; bonding strength is low when the thickness of the oxide layer reaches $1 \mu \mathrm{m}$.

The diffusion of elements during bonding at the interface is classified to two types: the diffusion of titanium atoms to porcelain and that of elements in porcelain to titanium or titanium oxide. The former diffusion has been studied by Kimura et $a l^{3}{ }^{3}$ They examined the effects of oxidation on porcelain/titanium interface reactions and bonding strength, and found a layer at the interface formed by the diffusion of titanium into the porcelain. In addition, Nagayama et $a l .{ }^{4}$ characterized the interface between titanium and porcelain using electron probe microanalysis and X-ray photoelectron spectroscopy (XPS). They revealed that titanium atoms diffused into the porcelain and that a reaction layer was formed, possibly 
corresponding to that found by Kimura et $a l^{3}{ }^{3}$. For the formation of the reaction layer, titanium atoms apparently diffuse into the porcelain during the firing process because currently only commercial pure titanium is used in porcelain-fused-to-titanium systems. The latter diffusion has been studied by some of the present authors ${ }^{5}$. We found that only sodium, potassium, and barium in commercial porcelain for titanium bonding diffused into the titanium during heating. After heating, the titanium oxide layer mainly consisted of titanium oxide whose valence was between trivalent and tetravalent and contained small amounts of sodium, potassium, and barium. These elements formed a complex oxide with titanium.

The above findings indicate that the bonding strength of a porcelain to titanium may be improved when the amount of alkaline or alkaline earth metals in the porcelain increase because these metallic elements easily diffuse into titanium oxide and form a complex oxide during firing. In the present study, the effect of the barium content in porcelain on the bonding strength of porcelain to titanium was investigated. Barium titanate which may form at the diffusion layer is known to be a high-inductive material. Since bonding strength is affected by the mismatch of thermal expansions in the porcelain and titanium, the coefficient of thermal expansion of porcelain containing barium was also estimated. In addition, bending strength was measured. These findings should enhance the understanding of the bonding of porcelain to titanium.

\section{MATERIALS AND METHODS}

\section{Preparation of specimens}

A commercial barium-free porcelain for titanium*5), which is used in direct contact with titanium, was employed as a starting material. The composition of the porcelain is summarized in Table ${ }^{5}$ ). Barium carbonate, $\mathrm{BaCO}_{3}$, powder** was added to the porcelain powder

Table 1 Relative concentrations of elements in the dental porcelain used in this study ${ }^{5}$

\begin{tabular}{cc}
\hline Element & Relative concentration (at.\%) \\
\hline $\mathrm{O}$ & 48.6 \\
$\mathrm{Ti}$ & 0.3 \\
$\mathrm{~B}$ & 3.7 \\
$\mathrm{Na}$ & 1.0 \\
$\mathrm{Al}$ & 7.9 \\
$\mathrm{Si}$ & 33.2 \\
$\mathrm{~K}$ & 3.2 \\
$\mathrm{Ca}$ & 0.7 \\
$\mathrm{Zn}$ & 0.1 \\
$\mathrm{Zr}$ & 0.9 \\
$\mathrm{Sn}$ & 0.4 \\
\hline
\end{tabular}

* Opaque, $\mathrm{A}_{3} \mathrm{O}$, Titan Bond, Ohara, Osaka, Japan

** Wako Pure Chemical Industries, Osaka, Japan 


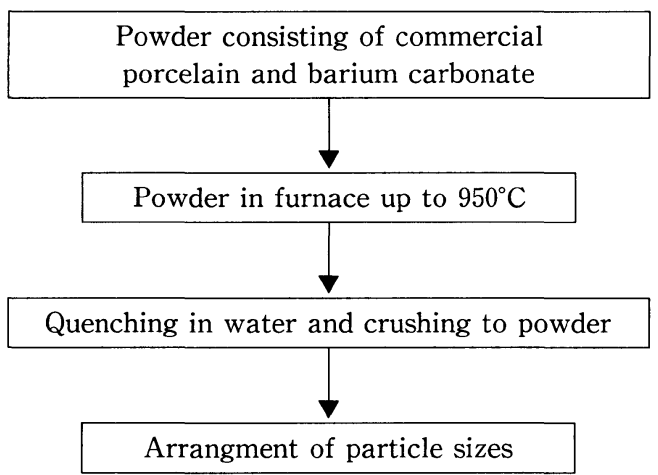

Fig. 1 Flowchart of the preparation of porcelain containing barium.

with resultant amounts of 5,10 , and 15 mass $\%$ of barium. The powders were mixed, fired to $950^{\circ} \mathrm{C}$ in a platinum crucible, and quenched in water. $\mathrm{BaCO}_{3}$ changed to $\mathrm{BaO}$ during this process. The resultant porcelain containing barium was crushed to powder with a mortar and pestle. The particle size of the powder was measured using a particle size analyzer\#. In addition, the powder was analyzed by an X-ray diffractometer\# (XRD). The manufacturing process of the barium-containing glassy porcelain is shown in Fig. 1. A titanium rod (ASTM grad. \#2) with $3 \mathrm{~mm}$ in diameter was finally polished with SiC \#1500 polishing paper and ultrasonically washed in acetone and ethanol for $900 \mathrm{~s}$ each.

\section{Shear bonding strength}

The porcelain powder was compressed around the titanium rod in a stainless steel mold with a pressure of $14 \mathrm{MPa}$ and the specimen as shown in Fig. 2 was eventually obtained. The porcelain powder with the titanium rod was fired at a rate of $30^{\circ} \mathrm{C} / \mathrm{min}$ to $800^{\circ} \mathrm{C}$ in a reduced pressure of $10 \mathrm{kPa}$. During firing, the titanium rod was supported by adiabatic blocks and the porcelain block around titanium did not contact anything during firing. The shear bonding strength was measured using a universal testing machine ${ }^{\circledR}$ and the shear strength was estimated per unit bonding area. The testing system is illustrated in Fig. 2. After the testing, the contact surface of the porcelain with titanium was analyzed with an energy dispersive $\mathrm{X}$-ray analyzer ${ }^{\circledR}$. . However, the main peaks of titanium and barium overlapped at an energy of approximately $4.5 \mathrm{keV}$. Therefore, the diffusion of barium into titanium oxide was not confirmed in this study. The results were analyzed with one-way ANOVA.

After the shear bonding test, the surface of titanium oxide caused by a fracture at the interface between titanium and titanium oxide described above was analyzed using XPS $\$$ to

\# CAPR-300, HORIBA, Tokyo, Japan

\# ADG-301, Toshiba, Tokyo, Japan

@ AG-100A, Shimadzu, Kyoto, Japan

@ @ EDX-700, Kevex, CA, USA

$\$$ ESCA-5500, Perkin-Elmer, Eden Prairie, MN, USA 
identify the diffusion of elements in the porcelain to titanium oxide. In other words, the analyzed surface was on the opposite side to the interface between the titanium oxide and the porcelain. In XPS, all binding energies given in the present paper are relative to the Fermi level and all spectra were obtained with the $\mathrm{Al} \mathrm{K} \alpha$ line: energy $1486.6 \mathrm{eV}$, voltage $14 \mathrm{kV}$, and current $10.7 \mathrm{~mA}$. The measurement area was a circle $800 \mu \mathrm{m}$ in diameter. The electron energy analyzer was operated in the constant analyzer energy mode at a pass energy of 11.75 $\mathrm{eV}$. The binding energies measured were calibrated with those of $\mathrm{Au} 4 \mathrm{f}_{7 / 2}(84.0 \mathrm{eV})$ and $\mathrm{Cu}$ $2 \mathrm{p}_{3 / 2}(932.7 \mathrm{eV})$. These values were obtained from a reference ${ }^{6}$. Resolution with full width at half-maximum (FWHM) of the $\mathrm{Ag} 3 \mathrm{~d}_{5 / 2}$ peak was $0.612 \mathrm{eV}$ under the experimental conditions and the binding energies were measured with an accuracy of $0.1 \mathrm{eV}$. The base pressure was $1.3 \times 10^{-8} \mathrm{~Pa}$ during the spectral acquisitions. The escape angle for photoelectron detection was $15^{\circ}$ ( $75^{\circ}$ from the surface of the specimen).

\section{Thermal expansion}

The porcelain powders containing barium were compressed in a stainless steel mold with a pressure of $10 \mathrm{MPa}$ and porcelain cylinder specimens with a dimension of $10 \mathrm{~mm}$ in diameter and $12-13 \mathrm{~mm}$ in height were obtained. The powder compacts were fired on platinum foil to $800^{\circ} \mathrm{C}$ at a rate of $30^{\circ} \mathrm{C} / \mathrm{min}$. $\Lambda \mathrm{fter}$ firing, the base surface was polished and the parallel base surfaces were obtained. The thermal expansion of each specimen was measured by a push $-\operatorname{rod}(4.5 \mathrm{~mm} \phi)$ differential dilatometer ${ }^{s s}$ from room temperature to contraction-onset tem-

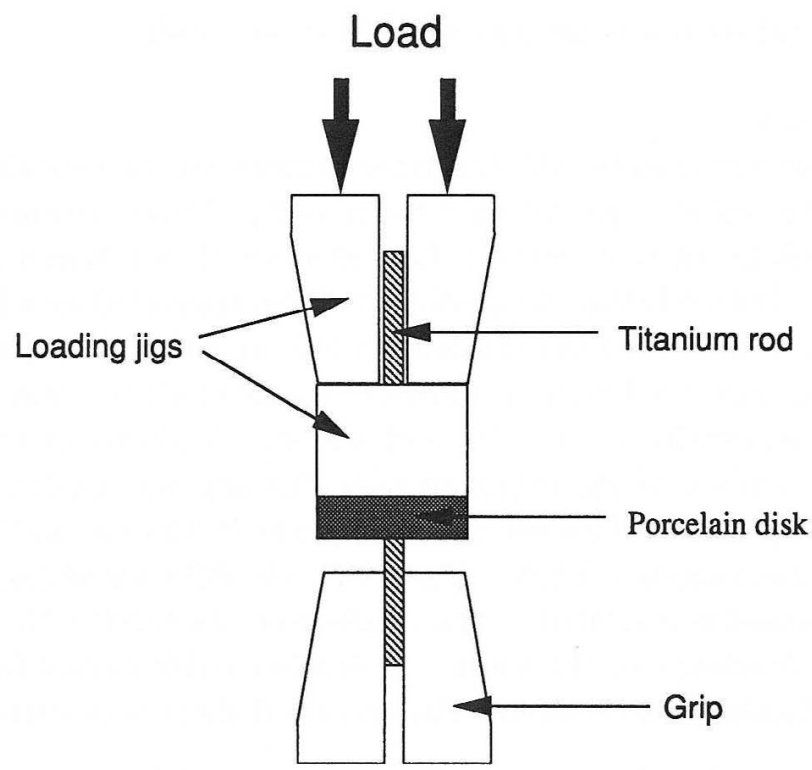

Fig. 2 Illustration of the testing system used to estimate the shear bonding strength between porcelain and titanium. 
perature at a rate of $5^{\circ} \mathrm{C} / \mathrm{min}$. The glass transition temperature $(\mathrm{Tg})$ was graphically determined from the thermal expansion curve.

\section{Bending strength}

The porcelain powders containing barium were compressed in a stainless steel mold with a pressure of $10 \mathrm{MPa}$ and the powder compacts were made with a dimension of $2 \mathrm{~mm} \times 7 \mathrm{~mm} \times$ $20 \mathrm{~mm}$. The powder compacts were fired on platinum foil to $800^{\circ} \mathrm{C}$ at a rate of $30^{\circ} \mathrm{C} / \mathrm{min}$. After firing, specimens to be measured for bending strength were grounded flat and parallel using a diamond rasp (\#700) to a final size of approximately $1.5 \mathrm{~mm} \times 6 \mathrm{~mm} \times 18 \mathrm{~mm}$ and polished with $0.5 \mu \mathrm{m}$ diamond polishing liquid. Bending strength was measured by a 3-point bending test with a span of $15 \mathrm{~mm}$, using the universal testing machine ${ }^{\circledR}$ at cross-head speed of $0.5 \mathrm{~mm} / \mathrm{min}$.

\section{RESULTS}

\section{Properties of barium-containing porcelain}

Average particle size of barium-free porcelains and porcelains containing barium before firing were $2.05 \mu \mathrm{m}$ for $0 \%$ and $1.43 \mu \mathrm{m}$ for $10 \%$. The XRD patterns obtained from the porcelain containing $10 \%$ of barium is shown in Fig. 3 as pattern of $\mathrm{C}$. For comparison, Fig. 3 shows the patterns obtained from $\mathrm{BaCO}_{3}$ powder $(\mathrm{A})$ and the starting commercial porcelain (B) used in this study. The diffraction pattern reveals that the starting porcelain possibly contained crystals of leucite, $\mathrm{SnO}_{2}$, and $\mathrm{ZrO}_{2}$ (Baddeleyite). These peaks were reduced in the
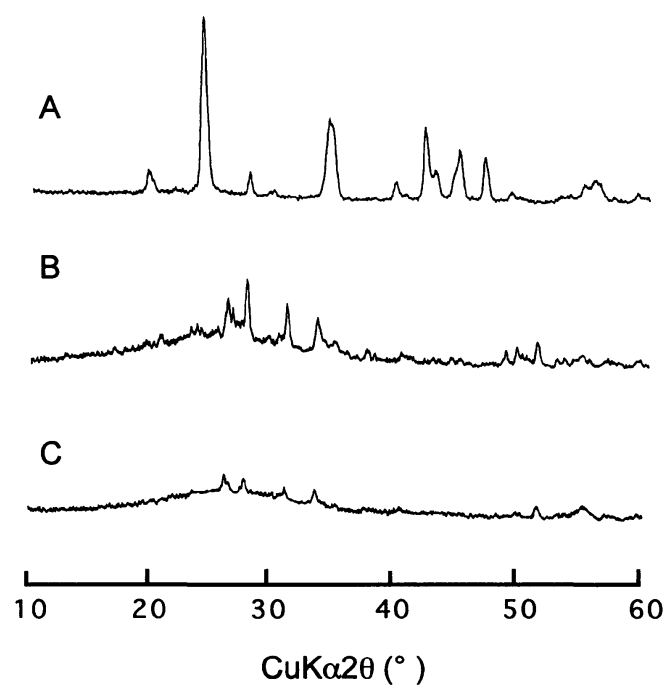

Fig. $3 \mathrm{X}$-ray diffraction patterns of $\mathrm{BaCO}_{3}$ powder (A), starting commercial porcelain* (B), and porcelain containing $10 \%$ barium (C). 


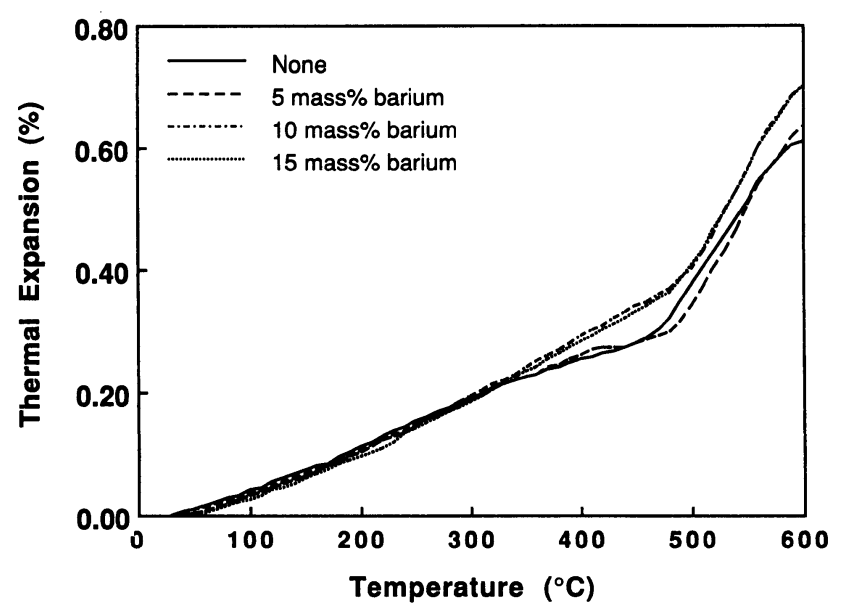

Fig. 4 Thermal expansion curves of porcelain containing barium and barium-free porcelain.

pattern from the resultant porcelain containing barium $(\mathrm{C})$, indicating that the crystals reacted with the glass in the porcelain and became a part of the glass components. No peak originating from $\mathrm{BaCO}_{3}$ and $\mathrm{BaO}$ was detected in the pattern from the porcelain containing barium (C). The thermal expansion curves as barium content are shown in Fig. 4. The coefficients of thermal expansion of the porcelains were $10 \times 10^{-6} /{ }^{\circ} \mathrm{C}$ under $\mathrm{T}_{g}$ and $30 \times$ $10^{-6} /{ }^{\circ} \mathrm{C}$ over $\mathrm{T}_{\mathrm{g}}$ in all porcelains with and without barium. The $\mathrm{Tg}$ was determined as $480^{\circ} \mathrm{C}$ in all porcelains.

\section{Shear bonding strength}

Shear bonding stresses of porcelains to titanium are shown in Fig. 5. The bonding strength significantly $(\mathrm{p}<0.05)$ increased with the increase of the barium content in the porcelain. The porcelain after shear bonding test is shown in Fig. 6. The surface of porcelain caused by a fracture at the interface between the porcelain and titanium is a dark tone, compared with porcelain bulk. On the other hand, the titanium surface after the test had luster. The micropiece of the dark-color substance described above may exist on the titanium surface.

\section{XPS of fractured interface}

The survey spectrum of XPS obtained from the dark-color surface caused by the fracture is shown in Fig. 7. Strong oxygen and titanium peaks were detected, indicating the dark-color surface is titanium oxide. Sodium silicon, calcium, and barium contained in the porcelain in addition to carbon, oxygen, and titanium, were clearly detected from the surface, which was also confirmed in spectra by narrow scanning. This indicates that the diffusion of sodium, calcium, and barium, as well as silicon, that is a main component of porcelain, diffused into titanium oxide, as revealed in a previous study ${ }^{5}$. The core level binding energies of barium and titanium were $779.6 \mathrm{eV}$ and $458.8 \mathrm{eV}$, respectively. The core level binding energy of 


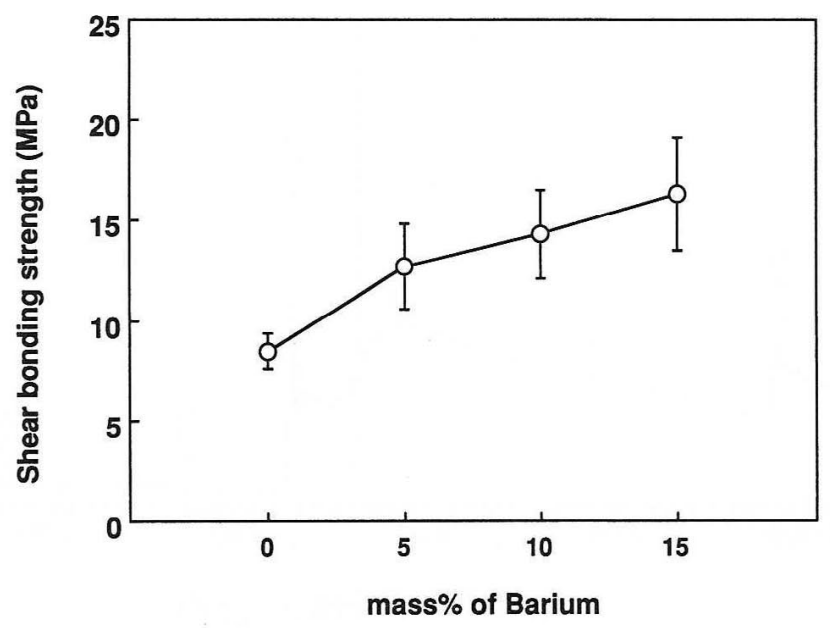

Fig. 5 Shear bonding strength of porcelain containing barium and barium-free porcelain with titanium rod.

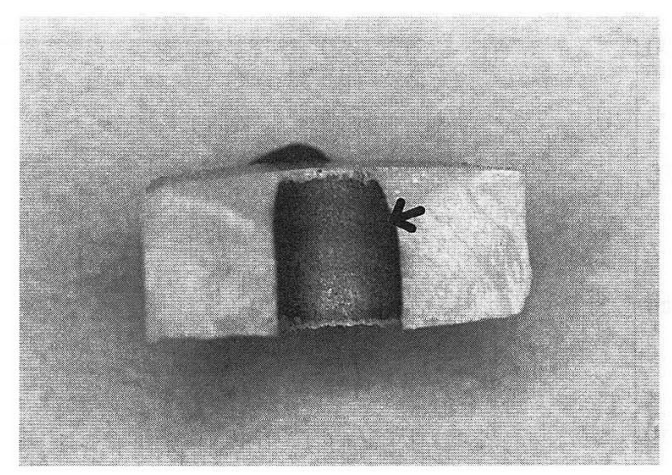

Fig. 6 Porcelain after shear bonding test. The arrow indicates the surface of titanium oxide caused by the fracture at the interface between the titanium and titanium oxide.

barium as barium metallate (no datum for $\mathrm{BaTiO}_{3}$ ) was $778.9-779.6 \mathrm{eV}$ and that for $\mathrm{BaO}$ was $779.9 \mathrm{eV}^{7}$. On the other hand, that of titanium for $\mathrm{BaTiO}_{3}$ was $458.55 \mathrm{eV}$ and that for $\mathrm{TiO}_{2}$ was $458.7 \mathrm{eV}^{7}$. Therefore, the chemical state of barium in titanium oxide could not be determined though it is possibly oxide and/or titanate.

\section{Bending strength}

The change in the bending strength of the porcelain is shown in Fig. 8. The mean value of the strength seems to increase according to the barium content while no significant difference 


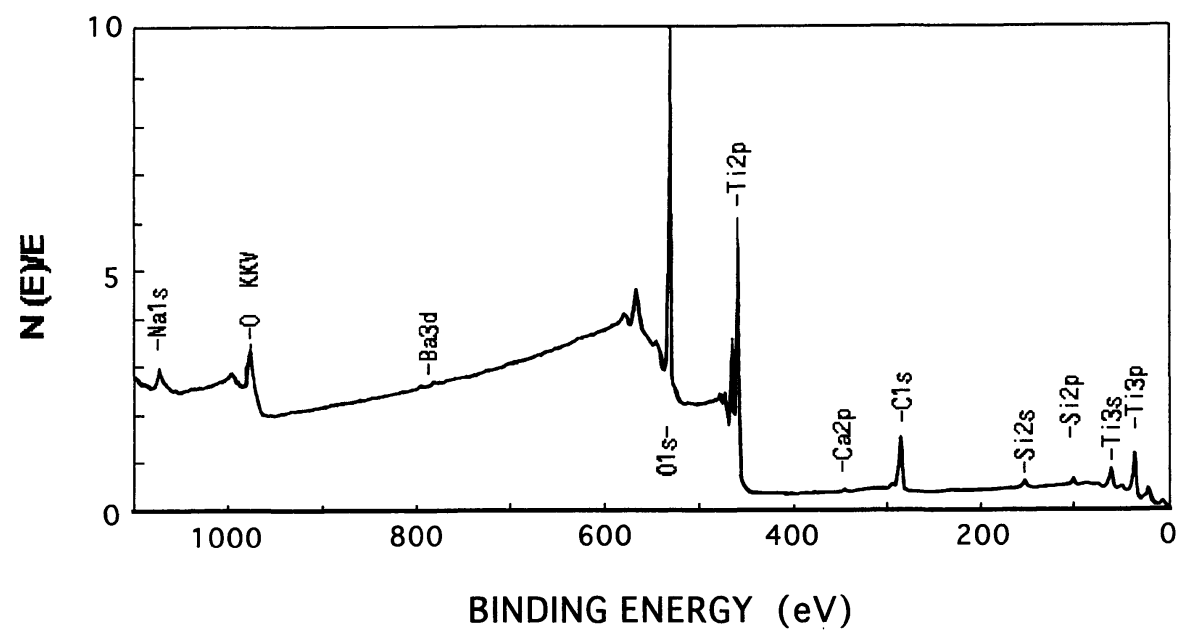

Fig. 7 Survey spectrum of XPS obtained from the surface of titanium oxide caused by the fracture at the interface between the titanium and titanium oxide.

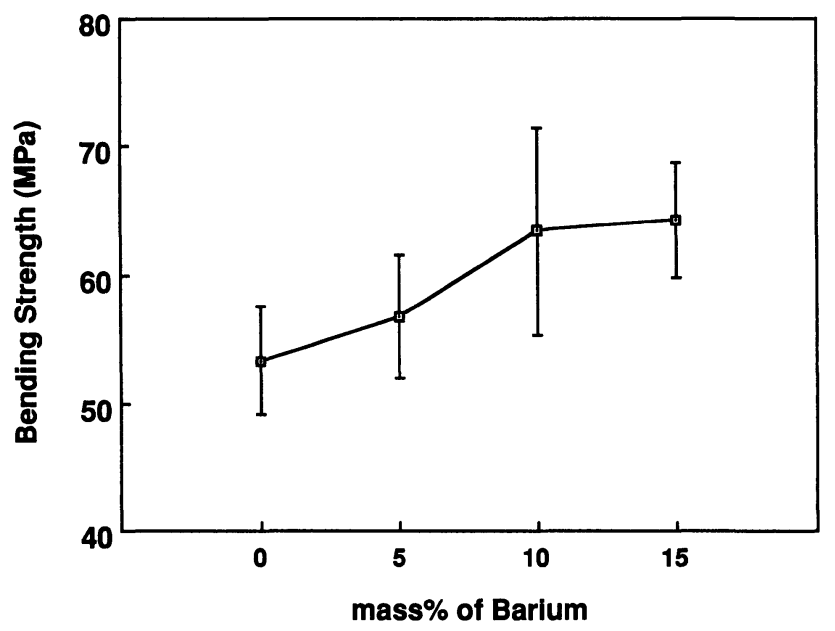

Fig. 8 Bending strength of porcelain containing barium and barium-free porcelain.

was observed $(\mathrm{p}<0.05)$. This indicates that the addition of barium up to $15 \%$ does not strengthen nor decrease the strength of the porcelain.

\section{DISCUSSION}

The coefficient of thermal expansion of porcelain was constant at $10 \times 10^{-6} /{ }^{\circ} \mathrm{C}$ under $480^{\circ} \mathrm{C}$ 
and $30 \times 10^{-6} /{ }^{\circ} \mathrm{C}$ over $480^{\circ} \mathrm{C}$ in spite of the addition of barium. The thermal expansion of glass usually increases by the addition of metallic oxides ${ }^{8)}$. No change in thermal expansion is favorable because the increase of thermal expansion of porcelain causes a mismatch with that of titanium during firing, which may decrease the bonding strength of porcelain with titanium. The coefficient of thermal expansion of titanium is $8.8-9.2 \times 10^{-6} /{ }^{\circ} \mathrm{C}$ from 20 to $800^{\circ} \mathrm{C}^{9}$.

The bonding strength of porcelain to titanium increased with the increase of barium. In addition, the porcelain did not fracture in the bulk but fractured at the interface between the titanium and titanium oxide and/or in the titanium oxide because a titanium oxide layer existed on the porcelain after the bonding test. These findings indicate that barium in porcelain is responsible for the increase in bonding strength. Here, the addition of another oxide, e.g. boron oxide, could possibly decrease thermal expansion ${ }^{8)}$ and increase bonding strength. In porcelain for titanium, the larger amount of boron should be contained in porcelain compared with conventional porcelain to reduce thermal expansion ${ }^{8)}$ because the coefficient of thermal expansion of titanium is smaller than that of gold alloys and nickelchromium alloys ${ }^{10)}$. Most porcelains did not fracture during testing and fractures that occurred were at the interface between the titanium and titanium oxide layer and/or in the titanium oxide that increased the thickness during firing, indicating that the interface between the titanium and titanium oxide or in the titanium oxide was the weakest. Therefore, the bonding at the interface between titanium oxide and the porcelain is stronger than that at the titanium/titanium oxide interface or in the titanium oxide.

Barium diffuses into the titanium (oxide) during heating as shown in a previous study5). Also, in the present study, the diffusion of barium, as well as sodium, silicon, and calcium, in titanium oxide during the firing between porcelain and titanium was revealed using XPS. In addition, the elements diffused throughout all the titanium oxide because the elements were detected at the opposite side of the porcelain. The addition of barium in porcelain increases the bonding strength, suggesting that the diffusion of barium into titanium oxide during firing results in the increase of the bonding strength. In the present study, chemical state of barium in titanium oxide is unclear. However, barium diffused into titanium oxide forms a complex oxide ${ }^{5)}$ that is possibly barium titanate. It is easy to form barium titanate under experimental conditions because the free energy for the formation of barium titanate is lower than those of titanium oxide at $25^{\circ} \mathrm{C}^{11}$. Also, from the viewpoint of the equilibrium phase diagram, it is shown that barium titanate is easily formed ${ }^{12}$. Barium titanate is the most important high-inductive material in the field of electronics and easily formed ${ }^{13)}$.

Bending strength was almost constant and was not affected by barium content. The addition of metallic oxide usually weakens the strength of glass because of disruption in the continuity of the network of glass. If strength was to decrease in porcelain with the addition of barium, the addition of barium to porcelain for strength would be questionable. The strength of the porcelain bulk, as well as the bonding strength to titanium, is important. The addition of barium is effective in increasing bonding strength between porcelain and titanium without decrease in the strength of the porcelain.

Other alkaline and alkaline earth metals diffused in titanium oxide in the present study, i.e. sodium, and calcium, may increase the bonding strength by the addition of the elements. 
However, it is unclear at present if the addition of essential elements that are already contained in porcelain effectively increased the bonding strength to titanium.

\section{CONCLUSIONS}

The bonding strength between a commercial porcelain and titanium increased by the addition of barium to the porcelain in amounts of 5-15 mass\%. In addition, bending strength and thermal expansion were not affected by the barium content. The bonding strength increases by the diffusion of barium into the titanium oxide that forms at the interface between titanium and porcelain. Therefore, the addition of barium to porcelain is effective for strengthening the bonding of porcelain and titanium.

\section{ACKNOWLEDGMENTS}

We thank Drs. Hidemi Ukai and Koichi Murakami, Research Institute, IshikawajimaHarima Heavy Industries, Co., Ltd., Tokyo, Japan, for their assistance of XPS analysis.

\section{REFERENCES}

1) Togaya, T., Suzuki, M., Tsutsumi, S. and Ida, K.: An application of pure titanium to the metal porcelain, Dent Mater J 2 (2) : 210-219, 1983.

2) Adachi, M., Mackert, Jr., J. R., Parry, E. E. and Fairhurst, C. W. : Oxide adherence and porcelain bonding to titanium and Ti-6Al-4V alloy, J Dent Res 69 (6): 1230-1235, 1990.

3) Kimura, H., Horng, C.-J., Okazaki, M. and Takahashi, J.: Oxidation effects on porcelain-titanium interface reactions and bond strength, Dent Mater J 9 (1): 91-99, 1990.

4) Nagayama, K., Izumi, T., Kikui, T., Okazaki, M. and Noguchi, H.: Porcelain-fused-to-titanium system -EPMA, ESCA studies on the titanium surface and the interface between titanium and fused porcelain-, J Jpn Dent Mater 12 (S22): 224-225, 1993.

5) Hanawa, T., Kon, M., Ohkawa, S. and Asaoka, K. : Diffusion of elements in porcelain into titanium oxide, Dent Mater J 13 (2) : 164-173, 1994.

6) Anthony, M. T. and Sea, M. P.: XPS : Energy calibration of electron spectrometer 1. -An absolute, traceable energy calibration and the provision of atomic reference line energies, Surf Interface Anal 6: 95-106, 1984.

7) Practical Surface Analysis, 2nd ed., Vol. 1, Auger and X-ray Photoelectron Spectroscopy, Briggs, D. and Seah, M. P. Eds., John Wiley \& Sons, New York, 1990.

8) Sakuhana, S., Sakaino, T. and Takahashi, K. : Glass Handbook, 3rd ed., Asakura Shoten, Tokyo, 1979, pp. 694-696. (in Japanese)

9) Japan Institute of Metals ed., Kinzoku Data Book, 2nd ed., Maruzen, Tokyo, 1984, p. 13.

10) Kimura, H., Horng, C.-J., Okazaki, M. and Takahashi, J.: Thermal compatibility of titanium-porcelain system, J Osaka Univ Dent Sch 30: 43-52, 1990.

11) CRC Handbook of Chemistry and Physics, 67th ed., Weast, R. C. ed., CRC Press, Boca Raton, Florida, 1986, pp. D50-D93.

12) Levin, E. M. and McMurdie, H. F.: Phase Diagrams for Ceramists, 1975 Supplement, The American Ceramic Society, Columbus, Ohio, 1975, p. 100.

13) Mizuta, S. and Kawamoto, K. : Ceramic Materiasls, The University of Tokyo Press, Tokyo, 1986, pp. 16-17. (in Japanese) 
を示した. 形状が同じもの同士の混合では, いずれの形 状においても, 組み合わせる粒径が小さいほど強度は大 きくなる傾向を示した.ミクロフィラーを $30 \%$ 添加した
場合においても，同様の傾向を示し，特に，小さな球形 フィラーで大きな強度を示した。

\section{陶材内のバリウム含有量がチタン/陶材接合強さに与える影響 \\ 岡 謙次, 塙 隆夫 ${ }^{1}$, 今 政幸 ${ }^{1}$, 李 海衡 $^{1}$, 河野文昭, 友竹偉則, 松本直之, 浅岡憲三 ${ }^{1}$ \\ 徳島大学歯学部歯科補綴学第一講座 \\ ${ }^{1}$ 徳島大学歯学部歯科理工学講座}

市販チタン焼付用陶材に $\mathrm{BaCO}_{3}$ を混合, 溶解, 急冷し, $5 ， 10$ および 15 重量\%パリウムを含有した陶材粉末を 作製した.この陶材をチタン棒 ( $3 \mathrm{~mm} \phi)$ 周囲に焼付け 処理して引き抜き試験を行い, 陶材中のバリウム含有量 がチタン/陶材接合強さに与える影響を比較検討した。 そ の結果, バリウム含有量の増加に伴い, チタン/陶材接合 強さは有意に増加する傾向を示した.これは,チタン/陶 材接合部に陶材中のバリウムが拡散することによってバ
リウムを含有する層が形成されたためと考えられる。ま た，バリウム添加による陶材の機械的性質の劣化，およ び熱膨張係数の変化が考えられるため，曲げ強さと熱膨 張についても測定を行ったが，バリウム添加による変化 は認められなかった. したがって，陶材に対するバリウ ム添加は,チタン/陶材結合強さの向上に効果的であるこ とか゚示唆された。

\section{石膏系埋没材の加熱過程で発生する熱応力のシミュレーション \\ 浅岡憲三, John A. Tesk ${ }^{1}$ \\ 徳島大学歯学部歯科理工学講座}

${ }^{1}$ National Institute of Standards and Technology, Dental and Medical Materials

埋没材の加熱過程で生じる熱応力に関しては定性的な 議論がなされてきたにすぎない.この問題を明確にする ために, 軸対称半無限円筒を一定速度で加熱したときの 温度分布を理論解から計算した。この温度分布から熱膨 張, 鋳型材中の熱応力を計算する式を導き, 数値シミュ レーションを行った。材料として石高系クリストバライ 卜埋没材を選び, 熱拡散率, 弾性率, 熱膨張には実測值 を用いた. その結果，クリストバライトの相変態との関
係で熱応力が計算され，合金の鋳込み温度で，鋳型の表 面に压縮, 中心部に引張応力が存在することが明らかに された。 またこの応力が加熱速度と関係していること が示された．次に，鋳造リング内の鋳型の熱応力計算か ら, 鋳型には圧縮応力が生じていることが示された. 以 上の結果から，鋳型材の加熱速度，鋳型リングの熱膨張 は寸法適合精度を決める因子であり，ここでの方法が鋳 型の最適加熱プロセスの設計に有効であると結論した。 